6) R.W. Johnson and A.H. Daane, J. Pheys. Chem., 65, 909 (1961).

7) B.J. Curtis, Carbon, 4, 483 (1966).

8) J.A. Turnbull, M.S. Stagg and W.T. Eeles, Carbon, 3, 387 (1966).

9) W.V. Kotlensky, Carbon, 5, 409 (1967).
10) C.E. Lowell, J. Am. Ceram. Soc., 50, 142 (1967).

11) H.N. Murty, D.L. Biederman and E.A. Heintz, Fuel, 56, 305 (1977).

12) A. Ōya, R. Yamashita and S. Ōtani, Fuel, 58, 495 (1975).

論 文・Paper

\title{
$\mathrm{Na}_{2} \mathrm{O}-\mathrm{BaO}-\mathrm{Al}_{2} \mathrm{O}_{3}-\mathrm{TiO}_{2}$ ガラスの耐アルカリ性
}

\author{
鷹木 洋・小久保 正・田代 仁 \\ (京都大学 化学研究所)
}

(0〜30) $\mathrm{Na}_{2} \mathrm{O} ・(0 \sim 33) \mathrm{BaO} \cdot(8 \sim 23) \mathrm{Al}_{2} \mathrm{O}_{3}$ ・ (43〜62) $\mathrm{TiO}_{2}$ (mol\%) の組成の 融液を 板状ガラスに 成形後粉砕し, 得られたガラス粉末 $(297 \sim 500 \mu \mathrm{m} \phi) 2 \mathrm{~g}$ を $95^{\circ} \mathrm{C}$ の $2 \mathrm{~N} \mathrm{NaOH}$ 水溶液 $100 \mathrm{ml}$ に浸漬したところ，ガラスの重量減少率は， $\mathrm{TiO}_{2}$ 及び $\mathrm{BaO}$ 含有量が増加するにつれて低下し， $\mathrm{Na}_{2} \mathrm{O}$ を特に多量に含む場合を除いて $\mathrm{G} 20$ ガラス $\left(1 \mathrm{Li}_{2} \mathrm{O} \cdot 11 \mathrm{Na}_{2} \mathrm{O} \cdot 1 \mathrm{Al}_{2} \mathrm{O}_{3} \cdot 71 \mathrm{SiO}_{2} \cdot 16 \mathrm{ZrO}_{2}\right.$, $\mathrm{wt} \%$ ）のそれよりはるか低かった。 上記組成の $\mathrm{TiO}_{2}$ の一部を $\mathrm{ZrO}_{2}$ で置換すると, 更に重量 減少率が低下し，またその融液から繊維状ガラスを得ることができた。しかし，得られた繊維（60 $\sim 270 \mu \mathrm{m} \phi \times 5 \mathrm{~mm}) 5$ 本を $200 \mathrm{ml}$ の上記液に浸漬した後の直径減少量は $\mathrm{G} 20$ ガラスのそれより 大きかった.

以上の結果より，この系のガラスは水溶液の体積 $V$ に対するガラスの表面積 $A$ の割合 $A / V$ がある程度大きい時には侵食されにくいが， $A / V$ が小さい時には侵食されやすいと考えられた。 この系のガラスが $A / V$ の大きい時に侵食されにくいのは, $\mathrm{TiO}_{2}$ のアルカリ性水溶液中での溶解 度が極めて低く，また $\mathrm{Ba}^{2+}$ イオンがガラス表面の $\mathrm{TiO}_{2}$ に吸着しやすいためであると考えられ た.

この系のガラス繊維を $95^{\circ} \mathrm{C}$ のポルトランドセメント浸出液 $(\mathrm{NaOH} 0.88 \mathrm{~g}, \mathrm{KOH} 3.45 \mathrm{~g}$ 及び $\left.\mathrm{Ca}(\mathrm{OH})_{2} 0.48 \mathrm{~g} / \mathrm{l}\right)$ に浸漬した場合は, 192 時間後も直径隇少が認められなかった.

(1980 年 10 月 23 日受付)

\section{Alkaline Durability of $\mathrm{Na}_{2} \mathrm{O}-\mathrm{BaO}-\mathrm{Al}_{2} \mathrm{O}_{3}-\mathrm{TiO}_{2}$ Glasses}

\author{
Hiroshi TAKAGI, Tadashi KOKUBO and Megumi TASHIRO \\ (Institute for Chemical Research, Kyoto University
Gokasho, Uji-shi 611
}

Melts of the compositions in the $\mathrm{Na}_{2} \mathrm{O}-\mathrm{BaO}-\mathrm{Al}_{2} \mathrm{O}_{3}-\mathrm{TiO}_{2}$ system and those modified by the addition of some other oxides were formed into plates $(1 \sim 3 \mathrm{~mm}$ thick) and fibers $(60 \sim 300$ $\mu \mathrm{m} \phi)$ by pressing between two steel plates and by drawing up with a tip of $\mathrm{Pt}$ rod, respectively. The compositions from which clear glass plates were obtained are shown in Fig. 2 and Table 1. Clear glass fibers were obtained only from the compositions containing $\mathrm{ZrO}_{2}$ (Table 1).

$2 \mathrm{~g}$ of grains $(297 \sim 500 \mu \mathrm{m} \phi)$ converted from the plate glasses was immersed in a $100 \mathrm{ml}$ of $2 \mathrm{~N} \mathrm{NaOH}$ aqueous solution at $95^{\circ} \mathrm{C}$ for $18 \mathrm{~h}$. The weight loss due to corrosion decreased with increasing $\mathrm{TiO}_{2}$ and $\mathrm{BaO}$ contents of the glasses (Fig. 3) and also by the partial substitution of the $\mathrm{ZrO}_{2}$ for the $\mathrm{TiO}_{2}$ (Table 1). The weight loss of A-10 $\mathrm{Zr}$ glass $\left(10 \mathrm{Na}_{2} \mathrm{O}\right.$. $20 \mathrm{BaO} \cdot 20 \mathrm{Al}_{2} \mathrm{O}_{3} \cdot 40 \mathrm{TiO}_{2} \cdot 10 \mathrm{ZrO}_{2}$, mol\%) developed was $1 / 40$ of that of $\mathrm{G} 20$ glass $\left(1 \mathrm{Li}_{2} \mathrm{O} \cdot\right.$ $11 \mathrm{Na}_{2} \mathrm{O} \cdot 1 \mathrm{Al}_{2} \mathrm{O}_{3} \cdot 71 \mathrm{SiO}_{2} \cdot 16 \mathrm{ZrO}_{2}$, wt\%). The diameter reduction of fibers of $\mathrm{A}-10 \mathrm{Zr}$ glass, 
however, was 5 times of that of G 20 glass, when 5 pieces of them $(60 \sim 270 \mu \mathrm{m} \phi \times 5 \mathrm{~mm})$ were immersed in a $200 \mathrm{ml}$ of $2 \mathrm{~N} \mathrm{NaOH}$ aqueous solution at $95^{\circ} \mathrm{C}$ for $18 \mathrm{~h}$ (Fig. 4). The diameter reduction of $\mathrm{A}-10 \mathrm{Zr}$ glass fibers were suppressed effectively by the addition of a small amount of A-10 Zr glass grains or powdered chemicals of $\mathrm{TiO}_{2} \cdot 1.5 \mathrm{H}_{2} \mathrm{O}$ or $\mathrm{Ba}(\mathrm{OH})_{2}$. $8 \mathrm{H}_{2} \mathrm{O}$ to the solution (Table 3 ).

These results indicate that the alkaline durability of $\mathrm{A}-10 \mathrm{Zr}$ glass is strongly affected by $\mathrm{TiO}_{2}$ and $\mathrm{BaO}$ dissolved into the solution from the glass even when their amounts in the solution are extremely small: When the ratio of the glass surface area to the solution volume is high as in the case of the grain test, the amounts of $\mathrm{TiO}_{2}$ and $\mathrm{BaO}$ dissolved from the glass into the solution will soon exceed certain limits of allowance, respectively, resulting in suppression of the corrosion of the glass. When this ratio is low as in the case of the fiber test, the amounts of these constituents will not reach the above limits until the end of the test. The strong effects of $\mathrm{TiO}_{2}$ and $\mathrm{BaO}$ in suppressing the corrosion were ascribed to the low solubility of $\mathrm{TiO}_{2}$ in the $\mathrm{NaOH}$ aqueous solution (Fig. 6) and high adsorption capacity of $\mathrm{Ba}^{2+}$ ions on the $\mathrm{TiO}_{2}$ present at the glass surface.

No appreciable reduction in diameter was found with $\mathrm{A}-10 \mathrm{Zr}$ and $\mathrm{G} 20$ glass fibers after immersed in a Portland cement aqueous phase solution at $95^{\circ} \mathrm{C}$ for $192 \mathrm{~h}$.

[Received October 23, 1980].

Key-words : $\mathrm{Na}_{2} \mathrm{O}-\mathrm{BaO}-\mathrm{Al}_{2} \mathrm{O}_{3}-\mathrm{TiO}_{2}$ glass, Titanate glass, Aluminate glass, Fiber glass, Alkali-resistant glass, Alkaline durability, Chemical corrosion

\section{1. 緒言}

ポルトランドセメント補強用のガラス繊維は, 耐アル カリ性に優れていることが要求される ${ }^{1)}$. 耐アルカリ性 に優れたガラスとしては，これまでに $\mathrm{ZnO}_{2}$ 含有ケイ酸 ナトリウムガラスなど が知られているが，これらのガ ラスも, 長時間アルカリ性水溶液に浸漬されると次第に 侵食され，その機械的強度が低下する ${ }^{1}$ 。その原因は, 主にこれらのガラスが $\mathrm{SiO}_{2}$ を主成分とし，その $\mathrm{SiO}_{2}$ が $\mathrm{H}_{2} \mathrm{SiO}_{3}, \mathrm{HSiO}_{3}{ }^{-}, \mathrm{SiO}_{3}{ }^{2-}$ などとしてアルカリ性水溶 液中に溶解しやすいが ためと考えられる.これに対し， $\mathrm{TiO}_{2}$ は後述するように, その水和物の生成自由エネル ギーなどから，アルカリ性水溶液中に溶解しにくいと推 定されるので, この成分を主成分とするガラスは優れた 耐アルカリ性を示すのではないかと考えられる.

$\mathrm{SiO}_{2}$ を含をず $\mathrm{TiO}_{2}$ を主成分とするガラスで，普通 のるつぼ溶融法で得られるものとしては,これまでに $\mathrm{Na}_{2} \mathrm{O}-\mathrm{Al}_{2} \mathrm{O}_{3}-\mathrm{TiO}_{2}$ 系 ${ }^{4}, \mathrm{BaO}-\mathrm{Al}_{2} \mathrm{O}_{3}-\mathrm{TiO}_{2}$ 系 ${ }^{4)}$ 及び (1 $\left.\mathrm{Na}_{2} \mathrm{O}+1 \mathrm{BaO}\right)-\mathrm{Al}_{2} \mathrm{O}_{3}-\mathrm{TiO}_{2}$ 亲5)のガラスが知られて いる. そこで本研究では，これらの系を含む $\mathrm{Na}_{2} \mathrm{O}$ $\mathrm{BaO}-\mathrm{Al}_{2} \mathrm{O}_{3}-\mathrm{TiO}_{2}$ 系の種々の組成及びこの系の組成に 種々の成分を添加した組成のガラスについて，その耐ア ルカリ性を調べることにした．以下にその結果を報告す る.

\section{1 試料の調製}

\section{2. 実 験 方 法}

まず, $\mathrm{Na}_{2} \mathrm{O}-\mathrm{BaO}-\mathrm{Al}_{2} \mathrm{O}_{3}-\mathrm{TiO}_{2}$ 系の種々の組成及びこ の系の組成の一部を他の成分で置換したり，あるいはこ の系の組成に他の成分を添加した組成の融液のガラス形 成能を調ベ，その結果得られたガラスについて耐アルカ リ性を調べることにした.
試料の組成としては, $\mathrm{Na}_{2} \mathrm{O}-\mathrm{BaO}-\mathrm{Al}_{2} \mathrm{O}_{3}-\mathrm{TiO}_{2}$ 系の $(0 \sim 30) \mathrm{Na}_{2} \mathrm{O} \cdot(0 \sim 33) \mathrm{BaO} \cdot(8 \sim 25) \mathrm{Al}_{2} \mathrm{O}_{3} \cdot(42 \sim 62) \mathrm{TiO}_{2}$ (mol\%) 組 成, $10 \mathrm{Na}_{2} \mathrm{O} \cdot 20 \mathrm{BaO} \cdot 20 \mathrm{Al}_{2} \mathrm{O}_{3} \cdot 50 \mathrm{TiO}_{2}$ $(\mathrm{mol} \%)$ 組成 (A と呼ぶ. 以下同様) の $\mathrm{TiO}_{2} の 5 \sim$ $12 \mathrm{~mol} \%$ を $\mathrm{ZrO}_{2}$ で置換した組成, その中の一つの 10 $\mathrm{Na}_{2} \mathrm{O} \cdot 20 \mathrm{BaO} \cdot 20 \mathrm{Al}_{2} \mathrm{O}_{3} \cdot 40 \mathrm{TiO}_{2} \cdot 10 \mathrm{ZrO}_{2}(\mathrm{~mol} \%)$ 組成 (A-10 Zr) の $\mathrm{Na}_{2} \mathrm{O}$ の $2.5 \mathrm{~mol} \%$ を $\mathrm{Li}_{2} \mathrm{O}$ 又は $\mathrm{K}_{2} \mathrm{O}$ で, $\mathrm{BaO}$ の $5 \mathrm{~mol} \%$ を $\mathrm{CaO}$ 又は $\mathrm{SrO}$ で, $\mathrm{Al}_{2} \mathrm{O}_{3}$ の $5 \mathrm{~mol} \%$ を $\mathrm{Fe}_{2} \mathrm{O}_{3}$ で置換した組成, 及び $\mathrm{A}-10 \mathrm{Zr}$ 組成 $100 \mathrm{~mol}$ に対し $5 \mathrm{~mol}$ の $\mathrm{ZnO}, \mathrm{CdO}, \mathrm{SnO}, \mathrm{PbO}, \mathrm{MnO}$, $\mathrm{B}_{2} \mathrm{O}_{3}, \mathrm{SiO}_{2}, \mathrm{GeO}_{2}, \mathrm{TeO}_{2}, \mathrm{P}_{2} \mathrm{O}_{5}, \mathrm{~V}_{2} \mathrm{O}_{5}, \mathrm{Nb}_{2} \mathrm{O}_{5}, \mathrm{Ta}_{2} \mathrm{O}_{5}$ あるいは $\mathrm{MoO}_{3}$ を添加した組成を選んだ。

これらの組成の融液のガラス形成能は次のようにして 調べた. 上記の組成のバッチ $30 \sim 60 \mathrm{~g}$ を化学薬品の酸 化物, 炭酸塩又は水酸化物を用いて調製し, 容積 $50 \mathrm{ml}$ の Pt 10\% Rh るつぼに入れ, Pt のふたをし, $\mathrm{SiC}$ 発 熱体電気炉中で $1500^{\circ} \mathrm{C}$ で 1 時間溶融した。 その後るつ ぼを炬外に取り出し, 自然に冷却し, その途中で融液を 直径 $1.5 \mathrm{~mm}$ の $\mathrm{Pt}$ 棒の先につけて引き上げ, 纎維状 に成形できるものについては，それを直径 60〜300 $\mu \mathrm{m}$ の繊維に成形した. その後るつぼを再び上記電気炉中に 入れ, $1500^{\circ} \mathrm{C}$ で 1 時間保持した後, 融液をステンレス 板上に流し出し，別のステンレス板で押さえ，厚さ 1 $3 \mathrm{~mm}$ の板に成形した.これらの方法により得られた繊 維状及び板状ガラスについて以下の実験を行った.

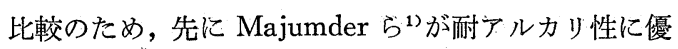
れたガラスとして報告した $\mathrm{ZrO}_{2}$ 含有ケイ酸ナトリウム ガラス G $20\left(1 \mathrm{Li}_{2} \mathrm{O} \cdot 11 \mathrm{Na}_{2} \mathrm{O} \cdot 1 \mathrm{Al}_{2} \mathrm{O}_{3} \cdot 71 \mathrm{SiO}_{2} \cdot 16 \mathrm{ZrO}_{2}\right.$, $\mathrm{wt} \%$ ）も同様の方法で調製した.

\section{2 耐アルカリ性の測定}




\subsection{1 粉 末 法}

先の実験で得られた板状ガラスの一部を WC 製のミ キサーミル (Spex Industries, Inc. No. 8000) により 粉研し，ステンレス製のふるいを通して $-32+48$ メッ シュ $(297 \sim 500 \mu \mathrm{m})$ の粒度の粉末を採取した。これを

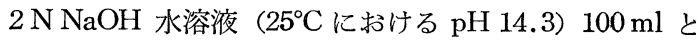
ともにポリプロピレン製の三角フラスコ（容量 $250 \mathrm{ml}$ ) に入れ，シリコンゴム製の栓をして， $95^{\circ} \mathrm{C}$ の油槽中に 置き，毎分 120 ストローク（ストローク長 $30 \mathrm{~mm}$ ) の 速度で 18 時間振とらした. この後, フラスコ内の固形 物を平均孔径 $2 \sim 5 \mu \mathrm{m}$ のテフロン製沪紙を用いて沪別 し, 蒸留水, $0.1 \mathrm{~N} \mathrm{HCl}$ 水溶液及びエチルアルコールで 洗浄した後, $125^{\circ} \mathrm{C}$ で約 15 時間乾操し, その固形物を ひょう量して $\mathrm{NaOH}$ 処理によるガラス粉末の重量減少 率を求めた. この実験を一つの組成のガラスについて試 料をかえて 3〜5 回行い, それらの重量減少率の平均值 をその組成のガラスの耐アルカリ性を示す一つの指標と した.

比較のため，一部のガラスについては，ガラス粉末の 量を $0.5 \sim 2 \mathrm{~g}$ の範囲で変化させ，また $\mathrm{NaOH}$ 水溶液 の量を $100 \sim 1800 \mathrm{ml}$ の範囲で変化させることにより， 水溶液の体積 $V$ に対する ガラス 重量 $W$ の割合 $W / V$ を $1 / 50 \sim 1 / 3600(\mathrm{~g} / \mathrm{ml})$ の範囲で変化させて同様の実験 を行った．ただし，水溶液の量が $1800 \mathrm{ml}$ の場合だけ は, これだけの量の水溶液を 1 度に三角フラスコに入れ

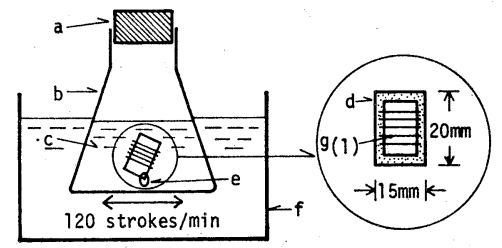

(A)

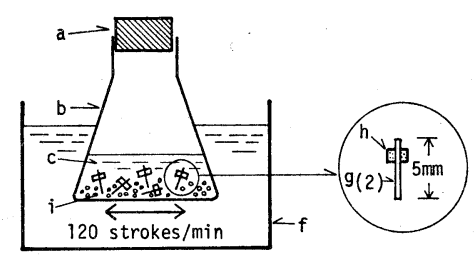

( B )

Fig. 1. Procedure for alkaline treatment of glass fibers, (A) $60 \sim 270 \mu \mathrm{m}$ and (B) $250 \sim 300$ $\mu \mathrm{m}$ in diameter; (a) Silicone ruber stopper, (b) Polypropylene flask, (c) Aqueous solution used for leaching glasses, (d) Polypropylene flame, (e) Pt ring, (f) Oil bath kept at $95^{\circ} \mathrm{C},\left(\mathrm{g}_{(1)}\right)$ glass fiber $60 \sim 270 \mu \mathrm{m}$ in diameter, $\left(\mathrm{g}_{(2)}\right)$ glass fiber 250 300 $\mu \mathrm{m}$ in diameter, (h) Polypropylene fragment and (i) Glass grains $297 \sim 500 \mu \mathrm{m}$ in diameter.
ることができないので， $200 \mathrm{ml}$ の水溶液を 2 時間ごと に 9 回入れ替えて実験を行った.

\subsection{2 繊 維 法}

先の実験で得られた直径 $60 \sim 270 \mu \mathrm{m}$ の繊維状ガラス から長さ約 $15 \mathrm{~mm}$ の試料を切り取り，直径のそろった もの 5 本ずつを図 1(A) に示すように電熱コテによりポ リプロピレン製の枠 $(20 \times 15 \mathrm{~mm}$, 厚さ $1 \mathrm{~mm})$ に溶着 し, それらの直径を光学顕微鏡下で $\pm 1 \mu \mathrm{m}$ の精度で測 定した。これらのガラス繊維を蒸留水及びエチルアルコ 一ルで洗浄し, 自然乾燥した後, 図 1(A) に示すように ポリプロピレン製の枠に $\mathrm{Pt}$ 線の重りをつけ, $2 \mathrm{~N} \mathrm{NaOH}$ 水溶液 $200 \mathrm{ml}$ とともにポリプロピレン製の三角フラス コ（容量 $250 \mathrm{ml}$ ) に入れ, シリコーンゴム製の栓をし, 粉末法の場合と同様に $95^{\circ} \mathrm{C}$ の油槽中で 18 時間振とう した.この場合に粉末法の場合に $100 \mathrm{ml}$ であった水溶 液の量を $200 \mathrm{ml}$ にしたのは，ポリプロピレン製の枠を 完全に水溶液中に浸すためである. 上記の浸漬後, ガラ ス繊維を枠につけたまま三角フラスコから取り出し, 蒸 留水, $0.1 \mathrm{~N} \mathrm{HCl}$ 水溶液及び エチルアルコールで洗浄 し, 自然乾燥した後再びそれらの直径を光学顕微鏡下で 測定し, その $\mathrm{NaOH}$ 処理による減少量を求めた. ただ し, ガラス纎維の表面に内部と屈折率の異なる薄層が観 察される場合には，それをピンセットでかき落してから その直径を測定した５本のガラス繊維について求めた 直径減少量の平均值を, その組成のガラスの耐アルカリ 性を示す別の一つの指標とした.

比較のため, 上記の $2 \mathrm{~N} \mathrm{NaOH}$ 水溶液の代わりにポ ルトランドセメントから漫出する成分を含む水溶液 (液 11 当り $\mathrm{NaOH} 0.88 \mathrm{~g}, \mathrm{KOH} 3.45 \mathrm{~g}$ 及び $\mathrm{Ca}(\mathrm{OH})_{2}$ $0.48 \mathrm{~g}$ を含夕, $25^{\circ} \mathrm{C}$ に䏠ける $\mathrm{pH} 12.9$, Majumder ら による．以後ポルトランドセメントしん出液と記す）を 用い，侵食時間を 18 時間加 192 時閒に変えて上記と 同様の実験を行った。 また，直径 $250 \sim 300 \mu \mathrm{m}$ の比較 的太い繊維状ガラス 5 本を図 1 (B) に示すように，1本 ずつポリプロピレンの小片に溶着し，2.2.1 項に記した のと同様の方法により調製した同じ組成のガラス粉末 2 $\mathrm{g}$ とともに，100 $\mathrm{ml}$ の $2 \mathrm{~N} \mathrm{NaOH}$ 水溶液中に浸漬し， 上記と同様に 18 時間処理してそれらの纎維の直径減少 量を調べることも行った.この時,繊維状ガラスを 1 本ず つばらばらにしたのは，これらがガラス粉末とよくまざ るようにするためであり，比較的太い繊維状ガラスを用 いたのは，これらがガラス粉末に触れた時に折れないよ うにするためである．また，䋊維状ガラスの 1 本ずつに ポリプロピレンの小片を溶着したのは，これを繊維の直 径を測定する位置を定める基準点とするためである. 一 方, 酸化物に換算して $2 \mathrm{mg}$ に相当する量の $\mathrm{NaOH}$, $\mathrm{Ba}(\mathrm{OH})_{2} \cdot 8 \mathrm{H}_{2} \mathrm{O}, \mathrm{Al}(\mathrm{OH})_{3}, \mathrm{TiO}_{2} \cdot 1.5 \mathrm{H}_{2} \mathrm{O}$ 及び $\mathrm{ZrO}_{2}$. $2.7 \mathrm{H}_{2} \mathrm{O}$ の粉末（粒径 $74 \mu \mathrm{m}$ 以下）をあらかじめ単独 
又は組み合わせて添加しておいた $100 \mathrm{ml} の 2 \mathrm{~N} \mathrm{NaOH}$ 水溶液中に，上記と同じ太い繊維状ガラス 5 本を浸漬 し, 同様に 18 時間処理してそれらの繊維の直径隇少量 を調べることも行った。

\section{3. 結 \\ 3.1 融液のガラス化傾向}

果

$\mathrm{Na}_{2} \mathrm{O}-\mathrm{BaO}-\mathrm{Al}_{2} \mathrm{O}_{3}-\mathrm{TiO}_{2}$ 系の融液を厚さ $0.5 \sim 2 \mathrm{~mm}$ の板状に成形した場合の融液のガラス化傾向に関して は, 先に小久保ら (2) が $\mathrm{Na}_{2} \mathrm{O}-\mathrm{Al}_{2} \mathrm{O}_{3}-\mathrm{TiO}_{2}$ 系及び $\mathrm{BaO}-$ $\mathrm{Al}_{2} \mathrm{O}_{3}-\mathrm{TiO}_{2}$ 系について, また Bayer ら゙が $\left(1 \mathrm{Na}_{2} \mathrm{O}+\right.$ $1 \mathrm{BaO})-\mathrm{Al}_{2} \mathrm{O}_{3}-\mathrm{TiO}_{2}$ 系について報告している. (1 $\mathrm{Na}_{2} \mathrm{O}$ $+2 \mathrm{BaO})-\mathrm{Al}_{2} \mathrm{O}_{3}-\mathrm{TiO}_{2}$ 系の融液のガラス化傾向につい て本研究で得られた結果を図 2 に示す. 図 2 亿は参考の ため, 先に報告された $\mathrm{Na}_{2} \mathrm{O}-\mathrm{Al}_{2} \mathrm{O}_{3}-\mathrm{TiO}_{2}$ 系, $\mathrm{BaO}$ $\mathrm{Al}_{2} \mathrm{O}_{3}-\mathrm{TiO}_{2}$ 系及び $\left(1 \mathrm{Na}_{2} \mathrm{O}+1 \mathrm{BaO}\right)-\mathrm{Al}_{2} \mathrm{O}_{3}-\mathrm{TiO}_{2}$ 系 の融液のガラス化傾向も示してある. 図 2 の実線又は点 線で囲まれた組成域内に扔いては，いずれの系において も肉眼でほとんど又は全く失透生成物の認められない板 状ガラスが得られる.

$\mathrm{Na}_{2} \mathrm{O}-\mathrm{BaO}-\mathrm{Al}_{2} \mathrm{O}_{3}-\mathrm{TiO}_{2}$ 亲の融液を 2.1 節の方法に より繊維状に成形した場合には，上記の $\mathrm{Na}_{2} \mathrm{O}-\mathrm{Al}_{2} \mathrm{O}_{3}-\mathrm{TiO}_{2}, \quad \mathrm{BaO}-\mathrm{Al}_{2} \mathrm{O}_{3}-\mathrm{TiO}_{2}$, $\left(1 \mathrm{Na}_{2} \mathrm{O}+1 \mathrm{BaO}\right)-\mathrm{Al}_{2} \mathrm{O}_{3}-\mathrm{TiO}_{2}$ 及び (1 $\left.\mathrm{Na}_{2} \mathrm{O}+2 \mathrm{BaO}\right)-\mathrm{Al}_{2} \mathrm{O}_{3}-\mathrm{TiO}_{2}$ のいずれ の系においてもガラスはほとんど得られ なかった。

$\mathrm{Na}_{2} \mathrm{O}-\mathrm{BaO}-\mathrm{Al}_{2} \mathrm{O}_{3}-\mathrm{TiO}_{2}$ 系の $10 \mathrm{Na}_{2} \mathrm{O}$. $20 \mathrm{BaO} \cdot 20 \mathrm{Al}_{2} \mathrm{O}_{3} \cdot 50 \mathrm{TiO}_{2}(\mathrm{~mol} \%)$ ) 組成 (A) の $\mathrm{TiO}_{2}$ の一部を $\mathrm{ZrO}_{2}$ で置換す ると，表 1 亿示すように，板状ガラスだ けでなく繊維状のガラスも得られるよう になった. 更に, $10 \mathrm{Na}_{2} \mathrm{O} \cdot 20 \mathrm{BaO} \cdot 20$ $\mathrm{Al}_{2} \mathrm{O}_{3} \cdot 40 \mathrm{TiO}_{2} \cdot 10 \mathrm{ZrO}_{2}$ (mol\%) 組成 (A-10 Zr) の一部を他の成分で置換する か，若しくはこれに他の成分を添加する と, 表 1 に示すように, $\mathrm{BaO}$ の一部を $\mathrm{SrO}$ で置換した場合, 及び $\mathrm{PbO}, \mathrm{CdO}$, $\mathrm{Ta}_{2} \mathrm{O}_{5}, \mathrm{~B}_{2} \mathrm{O}_{3}$ あるいは $\mathrm{GeO}_{2}$ を添加し た場合に特に繊維状ガラスが得られやす くなった. 2.1 節の方法により,繊維状ガ ラスにすることのできたこれら融液は, いずれも通常の短繊維製造法の一つであ る，蒸気吹き付け法 ${ }^{6)}$ にょっても容易に 繊維状ガラスにすることができた. しか しこれらは，穴の融液を白金ノズルから 連続的に引き出す通常の長繊維製造法で は，䋊維状ガラスにすることが容易でな

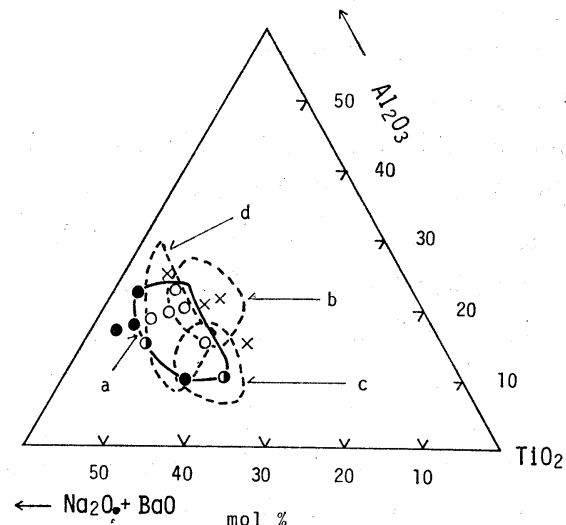

Fig. 2. Glass-forming tendency of melts in the $\left(1 \mathrm{Na}_{2} \mathrm{O}+2 \mathrm{BaO}\right)-\mathrm{Al}_{2} \mathrm{O}_{3}-\mathrm{TiO}_{2}$ system, when they are formed into a plate $1 \sim 3 \mathrm{~mm}$ thick; (O) clear glass, (†) almost clear glass, (O) partially devitrified glass and $(X)$ fully devitrified glass or imperfect melt. The region enclosed by solid line is glass-forming region in the (a) $\left(1 \mathrm{Na}_{2} \mathrm{O}+\right.$ $2 \mathrm{BaO})-\mathrm{Al}_{2} \mathrm{O}_{3}-\mathrm{TiO}_{2}$ system, and the regions enclosed by dashed lines are those in the (b) $\mathrm{Na}_{2} \mathrm{O}-\mathrm{Al}_{2} \mathrm{O}_{3}-\mathrm{TiO}_{2}{ }^{4)}$, (c) $\mathrm{BaO}-\mathrm{Al}_{2} \mathrm{O}_{3}-\mathrm{TiO}_{2}{ }^{4}$ ) and (d) $\left.\left(1 \mathrm{Na}_{2} \mathrm{O}+1 \mathrm{BaO}\right)-\mathrm{Al}_{2} \mathrm{O}_{3}-\mathrm{TiO}_{2}{ }^{5}\right)$ systems.

Table 1. Glass-forming tendency of $10 \mathrm{Na}_{2} \mathrm{O} \cdot 20 \mathrm{BaO} \cdot 20 \mathrm{Al}_{2} \mathrm{O}_{3}$. $50 \mathrm{TiO}_{2}$ melts modified with some components and weight loss of their glass grains after immersed in $2 \mathrm{~N} \mathrm{NaOH}$ aqueous solution at $95^{\circ} \mathrm{C}$ for $18 \mathrm{~h}$.

\begin{tabular}{|c|c|c|c|c|c|c|c|c|c|c|c|}
\hline \multirow{2}{*}{ Sample } & \multicolumn{4}{|c|}{ Composition } & \multicolumn{3}{|c|}{$n$ (mole ratio) } & \multirow[b]{2}{*}{ MmOn } & \multicolumn{2}{|c|}{$\begin{array}{l}\text { Glass-forming } \\
\text { tendency }\end{array}$} & \multirow{2}{*}{$\begin{array}{c}\text { Weight } \\
\text { loss } \\
(\%)\end{array}$} \\
\hline & $\mathrm{Na}_{2} \mathrm{O}$ & $\mathrm{R}_{2} \mathrm{O}$ & $\mathrm{BaO}$ & $R^{\prime} O$ & $\mathrm{Al}_{2} \mathrm{O}_{3} \mathrm{Fe}_{2} \mathrm{O}_{3}$ & $\mathrm{TiO}_{2}$ & $\mathrm{ZrO}_{2}$ & & P1ate* & Fiber ${ }^{\dagger}$ & \\
\hline A & 10.0 & & 20.0 & & 20.0 & 50.0 & & & AA & C & 0.21 \\
\hline A- $5 \mathrm{Zr}$ & 10.0 & & 20.0 & & 20.0 & 45.0 & 5.0 & & AA & B & 0.16 \\
\hline A- $7 \mathrm{Zr}$ & 10.0 & & 20.0 & & 20.0 & 43.0 & 7.0 & & AA & B & 0.16 \\
\hline$A-10 z x$ & 10.0 & & 20.0 & & 20.0 & 40.0 & 10.0 & & AA & A & 0.05 \\
\hline $\mathrm{A}-12 \mathrm{Zr}$ & 10.0 & & 20.0 & & 20.0 & 38.0 & 12.0 & & $\mathrm{C}$ & A & $\cdots \cdots *$ * \\
\hline A-10ZrLi & 7.5 & $\mathrm{Li}_{2} 02.5$ & 20.0 & & 20.0 & 40.0 & 10.0 & & A & A & 0.13 \\
\hline A-10Zrk & 7.5 & $\mathrm{~K}_{2} 02.5$ & 20.0 & & 20.0 & 40.0 & 10.0 & & A & C & 0.23 \\
\hline $\mathrm{A}-10 \mathrm{ZrMg}$ & 10.0 & & 15.0 & $\mathrm{Mg05.0}$ & 020.0 & 40.0 & 10.0 & & $\mathrm{c}$ & $\mathrm{C}$ & --- \\
\hline $\mathrm{A}-10 \mathrm{ZrCa}$ & 10.0 & & 15.0 & $\mathrm{Ca} 05.0$ & 020.0 & 40.0 & 10.0 & & $\mathrm{~A}$ & B & 0.08 \\
\hline $\mathrm{A}-10 \mathrm{ZrSr}$ & 10.0 & & 15.0 & Sr0s.0 & 020.0 & 40.0 & 10.0 & & AA & AA & 0.12 \\
\hline $\mathrm{A}-10 \mathrm{ZrFe}$ & 10.0 & & 20.0 & & $15.0 \quad 5.0$ & 40.0 & 10.0 & & $\mathrm{AA}$ & B & 0.14 \\
\hline$A-10 Z r+Z n$ & 10.0 & & 20.0 & & 20.0 & 40.0 & 10.0 & $\mathrm{Zn} 05.0$ & A & $\mathrm{C}$ & 0.24 \\
\hline $\mathrm{A}-10 \mathrm{Zr}+\mathrm{Cd}$ & 10.0 & & 20.0 & & 20.0 & 40.0 & 10.0 & $\mathrm{Cd} 05.0$ & $\mathrm{AA}$ & $\mathrm{AA}$ & 0.11 \\
\hline$A-10 Z r+S n$ & 10.0 & & 20.0 & & 20.0 & 40.0 & 10.0 & Sn05.0 & $\mathrm{AA}$ & C & 0.17 \\
\hline $\mathrm{A}-10 \mathrm{Zr}+\mathrm{Pb}$ & 10.0 & & 20.0 & & 20.0 & 40.0 & 10.0 & $\mathrm{~Pb} 05.0$ & $\mathrm{AA}$ & AA & 0.26 \\
\hline$A-10 Z r+M n$ & 10.0 & & 20.0 & & 20.0 & 40.0 & 10.0 & $\mathrm{Mn} 05.0$ & A & A & 0.12 \\
\hline$A-10 Z r+B$ & 10.0 & & 20.0 & & 20.0 & 40.0 & 10.0 & $\mathrm{~B}_{2} \mathrm{O}_{3} 5.0$ & Al & AA & 0.35 \\
\hline$A-10 Z r+B i$ & 10.0 & & 20.0 & & 20.0 & 40.0 & 10.0 & $\mathrm{Bi}_{2} \mathrm{O}_{3} 5.0$ & A & A & 0.10 \\
\hline $\mathrm{A}-10 \mathrm{Zr}+\mathrm{Si}$ & 10.0 & & 20.0 & & 20.0 & 40.0 & 10.0 & $\mathrm{SiO}_{2} 5.0$ & B & B & $-\cdots$ \\
\hline $\mathrm{A}-10 \mathrm{Zr}+\mathrm{Ge}$ & 10.0 & & 20.0 & & 20.0 & 40.0 & 10.0 & $\mathrm{GeO}_{2} 5.0$ & $\mathrm{AA}$ & A & 0.14 \\
\hline $\mathrm{A}-10 \mathrm{Zr}+\mathrm{Te}$ & 10.0 & & 20.0 & & 20.0 & 40.0 & 10.0 & $\mathrm{TeO}_{2} 5.0$ & A & B & 0.22 \\
\hline$A-10 Z r+P$ & 10.0 & & 20.0 & & 20.0 & 40.0 & 10.0 & $\mathrm{P}_{2} \mathrm{O}_{5} 5.0$ & A & $\mathrm{C}$ & 0.25 \\
\hline$A-10 Z r+V$ & 10.0 & & 20.0 & & 20.0 & 40.0 & 10.0 & $\mathrm{~V}_{2} \mathrm{O}_{5} 5.0$ & $\mathrm{C}$ & $\mathrm{C}$ & .... \\
\hline$A-10 z r+N b$ & 10.0 & & 20.0 & & 20.0 & 40.0 & 10.0 & $\mathrm{Nb}_{2} \mathrm{O}_{5} 5.0$ & $\mathrm{AA}$ & B & 0.14 \\
\hline $\mathrm{A}-10 \mathrm{Zr}+\mathrm{Ta}$ & 10.0 & & 20.0 & & 20.0 & 40.0 & 10.0 & $\mathrm{Ta}_{2} \mathrm{O}_{5} 5.0$ & $\mathrm{AA}$ & $\mathrm{AA}$ & 0.13 \\
\hline$A-10 Z r+M o$ & 10.0 & & 20.0 & & 20.0 & 40.0 & 10.0 & $\mathrm{MoO}_{3} 5.0$ & + & C & $-\cdots$ \\
\hline
\end{tabular}

* AA: Clear glass, A: Almost clear glass, B: Partially devitrified glass, C: Fully devitrified glass or imperfect melt.

$+\mathrm{AA}$ : Clear and long glass fibers can be drawn, A: Clear glass fibers can be drawn, B: Partially devitrified glass fibers can be drawn, C: Glass fibers can not drawn.

clear glasses could not be obtained. 
かった。

\section{2 ガラスの耐アルカリ性}

\subsection{1 粉 末 法}

$\mathrm{Na}_{2} \mathrm{O}-\mathrm{BaO}-\mathrm{Al}_{2} \mathrm{O}_{3}-\mathrm{TiO}_{2}$ 系で $\mathrm{BaO} / \mathrm{Na}_{2} \mathrm{O}, \mathrm{BaO} / \mathrm{Al}_{2} \mathrm{O}_{3}$, $\mathrm{TiO}_{2} / \mathrm{Al}_{2} \mathrm{O}_{3}$ 及び $\mathrm{TiO}_{2} / \mathrm{BaO}$ のモル比を系統的に変化さ せた組成のガラスについて， $\mathrm{NaOH}$ 処理による粉末の 重量減少率を調べた結果を図 3(A)〜 (D) 、示す. 図中 の○印は，5回の測定の平均值である.図 $3(\mathrm{~A})$ には比 較のため，同様にして調べた G 20 ガラスについての測 定結果も示してある.図 3 より, $\mathrm{Na}_{2} \mathrm{O}-\mathrm{BaO}-\mathrm{Al}_{2} \mathrm{O}_{3}-\mathrm{TiO}_{2}$ 系のガラス粉末の $\mathrm{NaOH}$ 処理による重量減少率は, ガ ラス中の $\mathrm{TiO}_{2} / \mathrm{BaO}$ のモル比によっては余り変化しな いが, $\mathrm{BaO} / \mathrm{Na}_{2} \mathrm{O}, \mathrm{BaO} / \mathrm{Al}_{2} \mathrm{O}_{3}$ 及び $\mathrm{TiO}_{2} / \mathrm{Al}_{2} \mathrm{O}_{3}$ のモル 比が増大するにつれ，すなわちガラス中の $\mathrm{TiO}_{2}$ 及び $\mathrm{BaO}$ 含有量が大きくなるにつれ 著しく低下すること， 及びそれらの重量減少率は $\mathrm{Na}_{2} \mathrm{O}$ 含有量の特に多い場合 を除き， G 20 ガラスのそれより著しく低いことが分る. 本研究で得られた $\mathrm{Na}_{2} \mathrm{O}-\mathrm{BaO}-\mathrm{Al}_{2} \mathrm{O}_{3}-\mathrm{TiO}_{2}$ 系の ガラス 中で $\mathrm{TiO}_{2}$ 及び $\mathrm{BaO}$ 含有量の最大のものは, $30 \mathrm{BaO}$.
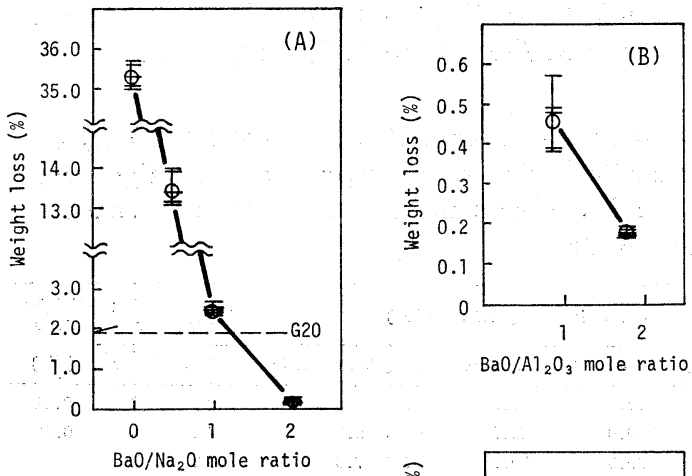

$\mathrm{BaO} / \mathrm{Al}_{2} \mathrm{O}_{3}$ mole ratio
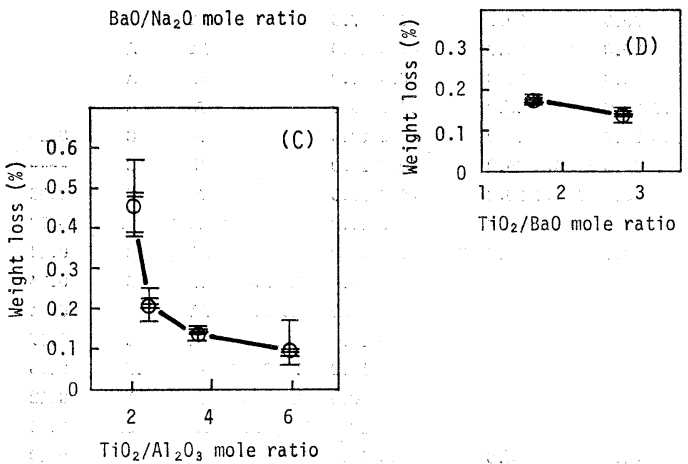

Fig. 3. Weight loss of $\mathrm{Na}_{2} \mathrm{O}-\mathrm{BaO}-\mathrm{Al}_{2} \mathrm{O}_{3}-\mathrm{TiO}_{2}$ glass grains $(2 \mathrm{~g})$ after immersed in $2 \mathrm{~N} \mathrm{NaOH}$ aqueous solution $(100 \mathrm{ml})$ at $95^{\circ} \mathrm{C}$ for $18 \mathrm{~h}$; $(-)$ measured value and (O) mean value. (A) $w \mathrm{Na}_{2} \mathrm{O} \cdot(30-w) \mathrm{BaO} \cdot 20 \mathrm{Al}_{2} \mathrm{O}_{3} \cdot 50 \mathrm{TiO}_{2}, \quad$ (B) 10 $\mathrm{Na}_{2} \mathrm{O} \cdot x \mathrm{BaO} \cdot(42.5-x) \mathrm{Al}_{2} \mathrm{O}_{3} \cdot 47.5 \mathrm{TiO}_{2}$, (C) 10 $\mathrm{Na}_{2} \mathrm{O} \cdot 20 \mathrm{BaO} \cdot y \mathrm{Al}_{2} \mathrm{O}_{3} \cdot(70-y) \mathrm{TiO}_{2}$ and (D) 10 $\mathrm{Na}_{2} \mathrm{O} \cdot z \mathrm{BaO} \cdot 15 \mathrm{Al}_{2} \mathrm{O}_{3} \cdot(75-z) \mathrm{TiO}_{2}$ glasses. $\mathrm{G} 20$ is the glass of composition $1 \mathrm{Li}_{2} \mathrm{O} \cdot 11 \mathrm{Na}_{2} \mathrm{O}$. $1 \mathrm{Al}_{2} \mathrm{O}_{3} \cdot 71 \mathrm{SiO}_{2} \cdot 16 \mathrm{ZrO}_{2}(\mathrm{wt} \%)$.
$8 \mathrm{Al}_{2} \mathrm{O}_{3} \cdot 62 \mathrm{TiO}_{2}(\mathrm{~mol} \%)$ 組成のガラスであり, その粉 末の重量減少率は $0.04 \%$ で， G 20 ガラスのそれの約 1/50 であった.

$\mathrm{Na}_{2} \mathrm{O}-\mathrm{BaO}-\mathrm{Al}_{2} \mathrm{O}_{3}-\mathrm{TiO}_{2}$ 系の $\mathrm{A}$ 組成の $\mathrm{TiO}_{2}$ の一部 を $\mathrm{ZrO}_{2}$ で置換した組成のガラス粉末についての, $\mathrm{NaOH}$ 処理による 重量減少率の測定結果を表 1 右欄に 記す。これらの值は，3回測定值を平均したものであ る. 表 1 から, A 組成の $\mathrm{TiO}_{2}$ の一部を $\mathrm{ZrO}_{2}$ で置換 すると重量減少率が低下することが分る. その結果, A$10 \mathrm{Zr}$ 組成のガラスは $\mathrm{BaO}$ 及び $\mathrm{TiO}_{2}$ を特に多量に含 むものでないにもかかわらず, その重量減少率は $0.05 \%$ で $\mathrm{G} 20$ ガラスのそれの約 $1 / 40$ であった.この A-10 Zr 組成の一部を他の成分で置換し，またこれに他の成分を 添加しても, そのガラス粉末の重量減少率はこれ以上に 減少しなかった.

$\mathrm{A}-10 \mathrm{Zr}$ ガラスについて, $\mathrm{NaOH}$ 水溶液の体積 $V$ に 対するガラス粉末の重量 $W$ の割合 $W / V$ を $1 / 50$ $1 / 3600(\mathrm{~g} / \mathrm{ml})$ の範囲で変化させて, $\mathrm{NaOH}$ 処理による 粉末の重量減少率を測定した結果を表 2 に示す. 表 2 に は比較のため，同様にして測定した G 20 ガラスについ ての結果も示した. 表 2 から, A-10 Zr ガラスの重量減 少率は，W/V が減少するにつれてかなり増加すること が分る．同様の傾向は， G 20 ガラスの場合にも認めら れるが，その増加の割合は A-10Zr ガラスの場合より 小さい. そのために $W / V$ が $1 / 3600(\mathrm{~g} / \mathrm{ml})$ の場合に は, A-10 Zr ガラスの重量減少率は G 20 ガラスのそれ にかなり近づくが，それでもなお後者の約 $1 / 4$ であっ た.

\subsection{2 繊 維 法}

2.1 節の方法で纎維状に成形でき, しかも粉末法で比 較的低い重量減少率を示した A-10 Zr ガラスについて， その繊維の $\mathrm{NaOH}$ 処理による直径減少量を調べた結果 を図 4 に示す. 測定は $60 \sim 270 \mu \mathrm{m}$ の種々の直径の繊維 について行った. 図 4 には比較のため, 同様にして調べ た G 20 ガラスの測定結果も示す. A-10 Zr ガラスの場 合には，図 5(A) に示すように, $\mathrm{NaOH}$ 処理後にその 表面に内部と屈折率の異なり，一部は，はく離の始まっ た薄層が認められたので，この薄層をできるだけかき落

Table 2. Weight loss of $\mathrm{A}-10 \mathrm{Zr}$ and $\mathrm{G} 20$ glass grains after immersed in $2 \mathrm{~N} \mathrm{NaOH}$ aqueous solution at $95^{\circ} \mathrm{C}$ for $18 \mathrm{~h}$ in various glass weight/ solution volume $(\mathrm{W} / \mathrm{V})$ ratio.

\begin{tabular}{ccccccccc}
\hline \multicolumn{8}{c}{ Weight } & loss $(\%)$ \\
\cline { 2 - 8 } Sample & Glass weight, $W$ & $(\mathrm{~g})$ & 2 & 1 & 1 & 0.5 & 0.5 \\
\cline { 2 - 8 } & Solution volume, $V(\mathrm{ml})$ & 100 & 100 & 200 & 200 & $200 \times 9$ \\
\hline W/V & $(\mathrm{g} / \mathrm{ml})$ & $1 / 50$ & $1 / 100$ & $1 / 200$ & $1 / 400$ & $1 / 3600$ \\
\hline A-10Zr & & 0.05 & 0.30 & 0.38 & 0.42 & 0.73 \\
G20 & & 1.93 & 2.10 & 2.54 & 2.29 & 3.06 \\
\hline
\end{tabular}


としてから直径を測定した.一方 G 20 ガラスの場合は，

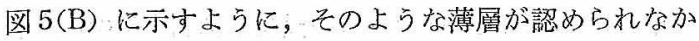
ったので，そのまま直径を測定した。図 4 より，A-10 Zr ガラスの繊維はいずれの直径の場合にも， $\mathrm{NaOH}$ 処 理により G 20 ガラスの繊維の約 5 倍の直径減少量を示 し，後者よりかなり侵食されやすいことが分る。この結 果は粉末法の場合と逆である.

同し A-10 Zr ガラスの直径 250〜300 $\mu \mathrm{m}$ の繊維を， それと同組成のガラス粉末 $2 \mathrm{~g}$ とををに $100 \mathrm{ml}$ の $2 \mathrm{~N} \mathrm{NaOH}$ 水溶液中に浸漬し，直径減少量を測定した結

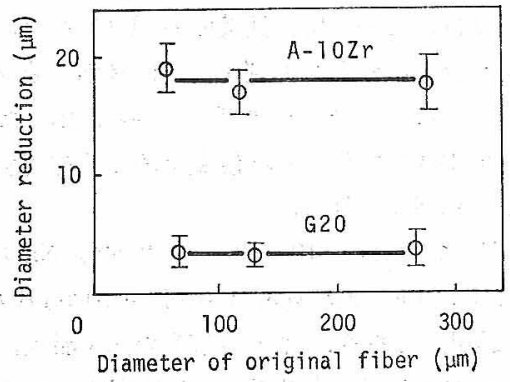

Fig. 4. Diameter reduction of $\mathrm{A}-10 \mathrm{Zr}$ glass fibers ( $15 \mathrm{~mm}$ in length, 5 pieces) with various diameter after immersed in $2 \mathrm{~N} \mathrm{NaOH}$ aqueous solutions $(200 \mathrm{ml})$ at $95^{\circ} \mathrm{C}$ for $18 \mathrm{~h}$; (O) mean value and (I) $95 \%$ confidence limits.

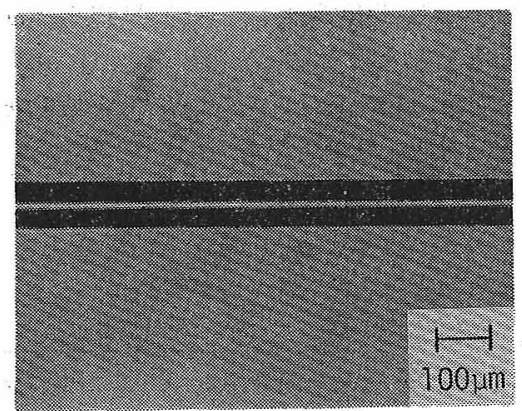

Before immersed

(A)

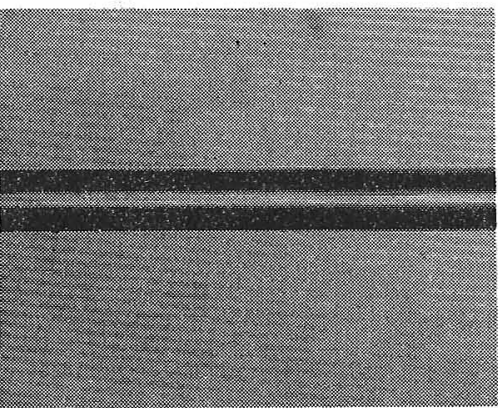

Before immersed
果を表 3 に示す. 表 3 には比較のため，同様にして求め た G20 ガラスの繊維についての測定結果も示す.また 表 3 には，参考のため $\mathrm{NaOH}$ 処理後のガラス繊維の表 面状態も示す。表 3 より明らかなように，ガラス粉末を 其存させた場合には， $\mathrm{A}-10 \mathrm{Zr}$ ガラスの絨維の $\mathrm{NaOH}$ 処理による直径減少量はほとんど $0 \mu \mathrm{m}$ で, 同じ条件の

Table 3. Diameter reduction of fiber of $\mathrm{A}$ $10 \mathrm{Zr}$ and $\mathrm{G} 20$ glasses $(250 \sim 300 \mu \mathrm{m} \phi \times 5 \mathrm{~mm}$, 5 pieces), and their appearance of surface after immersed in $2 \mathrm{~N} \mathrm{NaOH}$ aqueous solutions ( 100 $\mathrm{ml}$ ) at $95^{\circ} \mathrm{C}$ for $18 \mathrm{~h}$ together with some additives.

\begin{tabular}{|c|c|c|c|c|}
\hline Sample & Additive mat & erial & $\begin{array}{c}\text { Diameter } \\
\text { reduction } \\
(\mu \mathrm{m})\end{array}$ & $\begin{array}{l}\text { Appearance of } \\
\text { fiber surface }\end{array}$ \\
\hline \multirow{8}{*}{$A-10 z r$} & None & & 18 & cloudy \\
\hline & A-10Zn g1ass & $\begin{array}{r}\text { grains* } \\
2 \mathrm{~g}\end{array}$ & 0 & clear \\
\hline & $\mathrm{NaOH}$ & $2.6 \mathrm{mg}$ & 17 & cloudy \\
\hline & $\mathrm{Ba}(\mathrm{OH})_{2} \cdot 8 \mathrm{H}_{2} \mathrm{O}$ & $4.1 \mathrm{mg}$ & 6 & almost clear \\
\hline & $\mathrm{Al}(\mathrm{OH})_{3}$ & $3.1 \mathrm{mg}$ & 16 & cloudy \\
\hline & $\mathrm{TiO}_{2} \cdot 1.5 \mathrm{H}_{2} \mathrm{O}$ & $2.7 \mathrm{mg}$ & $\therefore \quad 3$ & cloudy \\
\hline & $\mathrm{ZrO}_{2} \cdot 2.7 \mathrm{H}_{2} \mathrm{O}$ & $2,8 \mathrm{mg}$ & $\therefore \quad 13$ & cloudy \\
\hline & Mixture of ab & $\begin{array}{l}\text { ove } \\
\text { drates }\end{array}$ & 3 & almost clear \\
\hline \multirow[t]{2}{*}{ G20 } & None & & 4 & clear \\
\hline & G20 g1ass gra & ins ${ }^{*} 2 g$ & 4 & clear \\
\hline
\end{tabular}

* 297-500um in diameter.

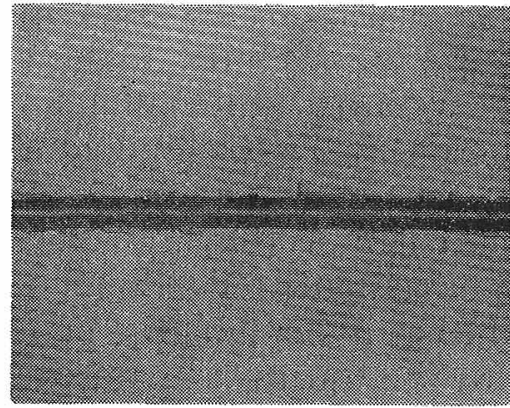

After immersed

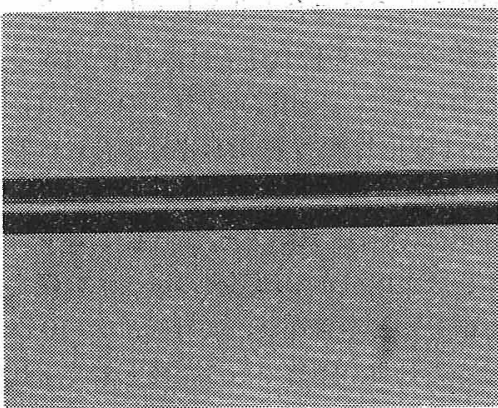

After immersed

(B)

Fig. 5. Optical micrograghs of (A) $\mathrm{A}-10 \mathrm{Zr}$ and (B) G 20 glass fibers $(60 \sim 80 \mu \mathrm{m} \phi \times 15 \mathrm{~mm}$, 5 pieecs) before and after immersed in $2 \mathrm{~N} \mathrm{NaOH}$ aqueous solution $(200 \mathrm{ml})$ at $95^{\circ} \mathrm{C}$ for $18 \mathrm{~h}$. 
下で処理した G 20 ガラスの繊維の直径減少量 $4 \mu \mathrm{m}$ よ り小さかった。この場合には，A-10 Zr ガラスの繊維の 表面にも，G 20 ガラスの 繊維の表面と同様に 薄層が認 められなかった.

あらかじめ A-10 Zr ガラスの種々の構成酸化物 $2 \mathrm{mg}$ を，水酸化物若しくは水和物の形で単独又は組み合わせ て添加しておいた $100 \mathrm{ml} の 2 \mathrm{~N} \mathrm{NaOH}$ 水溶液中に, 同ガラスの繊維を浸漬した場合の直径減少量も表 3 に示 す. 表 3 から， A-10 Zr ガラスの繊維の $\mathrm{NaOH}$ 処理に 上る直径減少量は, 水溶液中に $\mathrm{TiO}_{2} \cdot 1.5 \mathrm{H}_{2} \mathrm{O}$ 又は $\mathrm{Ba}(\mathrm{OH})_{2} \cdot 8 \mathrm{H}_{2} \mathrm{O}$ 粉末が添加されていると著しく減少す ることが分る.

$\mathrm{A}-10 \mathrm{Zr}$ ガラス及び $\mathrm{G} 20$ ガラスの直径 $60 \sim 80 \mu \mathrm{m}$ の繊維を，2.2.2 項に記した方法によりポルトランドセ メント浸出液に浸漬した場合には，192 時間浸漬後にも いずれのガラスについてもほとんど直径減少が認められ なかった。

\section{4. 考察}

先の実験より，A-10 Zr ガラスはガラス粉末 $2 \mathrm{~g}$ を $100 \mathrm{ml}$ の $\mathrm{NaOH}$ 水溶液に浸漬する粉末法においては, G 20 ガラスより侵食されにくいのに，ガラス繊維 5 本 だけを $200 \mathrm{ml}$ の $\mathrm{NaOH}$ 水溶液に浸漬する繊維法では, G 20 ガラスよりかえって侵食されやすいことが明らか になった。このように試験法によって異なった結果の得 られた原因は，G 20 ガラスの侵食速度は，水溶液の体 積 $V$ に対するガラスの表面積 $A$ の割合 $A / V$ によっ てほとんど変化しないのに対し，A-10 Zr ガラスのそれ は，その割合によって大きく変化するためであると考え られる。ガラスの侵食速度と $A / V$ の間にこのような関 係が存在することは，表 3 の実験結果より明らかであ る.すなわち，同実験において，ガラス繊維とともにガ ラス粉末 $2 \mathrm{~g}$ を $\mathrm{NaOH}$ 水溶液に浸漬した場合, G 20 ガラスの侵食量は，ガラス粉末を添加しない場合とほと んど変わらなかったのに対し，A-10 Zrr ガラスのそれ は，ガラス粉末を添加しない場合より著しく低下した。

このように, G20 ガラスの侵食速度は， $A / V$ によっ てほとんど変化しないのに，A-10 Zr ガラスのそれは， $A / V$ によって大きく変化し, $A / V$ が小さい場合には侵 食速度が大きく， $A / V$ がある值を越えると侵食速度が 著しく低下する理由は，G 20 ガラスについてはガラス から水溶液中に溶出した成分がそれ以後のガラスの侵食 を抑制する効果をほとんど示さないのに対し，A-10 Zr ガラスについてはその効果が顕著であるためと考えられ る.

表 3 によれば, $\mathrm{A}-10 \mathrm{Zr}$ ガラスの繊維の侵食量は, $\mathrm{NaOH}$ 水溶液にあらかじめ $\mathrm{TiO}_{2} \cdot 1.5 \mathrm{H}_{2} \mathrm{O}$ あるいは $\mathrm{Ba}(\mathrm{OH})_{2} \cdot 8 \mathrm{H}_{2} \mathrm{O}$ 粉末を添加しておいた場合に著しく低
下する。このことは， A-10 Zr ガラスから溶出した成分 の中で，それ以後の同ガラスの侵食を抑制するのに顕著 な効果をもつ成分は， $\mathrm{TiO}_{2}$ 及び $\mathrm{BaO}$ であることを示 していると考えられる. 表 2 によれば，A-10 Zr ガラス 粉末は, $\mathrm{NaOH}$ 水溶液の体積 $V$ に対するガラス重量 $W$ の割合 $W / V$ が $1 / 3600(\mathrm{~g} / \mathrm{ml})$ と小さい場合でも $\mathrm{G} 20$ ガラスより侵食されにくい.この場合の同ガラスの 18 時 間浸漬後の重量減少率は $0.73 \%$ であり，これは 3.65 $\mathrm{mg}$ の重量減少に相当する。この全量がすべて $\mathrm{TiO}_{2}$ あ るいは $\mathrm{BaO}$ の形でガラスから $\mathrm{NaOH}$ 水溶液へ溶出し たとしても，それらの濃度は $0.002 \mathrm{mg} / \mathrm{ml}$ にすぎない。 表 2 の結果は, この程度に低濃度の $\mathrm{TiO}_{2}$ や $\mathrm{BaO}$ でも $\mathrm{A}-10 \mathrm{Zr}$ ガラスの侵食を抑制するのに有効であること を示している．このようにガラスから溶出した微量の $\mathrm{TiO}_{2}$ 又は $\mathrm{BaO}$ がガラスの侵食を著しく抑制する原因 は次のように考えられる.

Auger ${ }^{7)}$ によれば， $10 \mathrm{wt} \%$ (約 $2.5 \mathrm{~N}$ ) $\mathrm{NaOH}$ 水溶 液中に抢ける $\mathrm{TiO}_{2}$ の溶解度は $0.02 \sim 0.025 \mathrm{~g} / 1(0.02 \sim$ $0.025 \mathrm{mg} / \mathrm{ml}$ ) である. この溶解度の測定温度は報告さ れていないので不明であるが，仮に室温での值であると すると, Spraner ら ${ }^{8)}$ にりり測定された $25^{\circ} \mathrm{C} の 8.68$ wt\% $\mathrm{Na}_{2} \mathrm{O}$ (約 $3.7 \mathrm{~N} \mathrm{NaOH)}$ 水溶液中に打ける $\mathrm{SiO}_{2}$ の溶解度 $2.97 \mathrm{wt} \%$ (約 $33.6 \mathrm{mg} / \mathrm{ml}$ ) に比べ極めて低 い.一方, Pourbaix ${ }^{9)}$ の著書によれば, $\mathrm{TiO}_{2}$ (ルチル) (cryst.), $\mathrm{TiO}(\mathrm{OH})_{2}$ (cryst.), $\mathrm{HTiO}_{3}^{-}{ }^{-}$(aq), $\mathrm{TiO}^{2+}$ (aq.), $\mathrm{H}_{2} \mathrm{O}$ 及び $\mathrm{OH}^{-}$(aq.) の標準生成自由エネルギーはそれ ぞれ $-212.330,-252.990,-228.460,-138.000$,
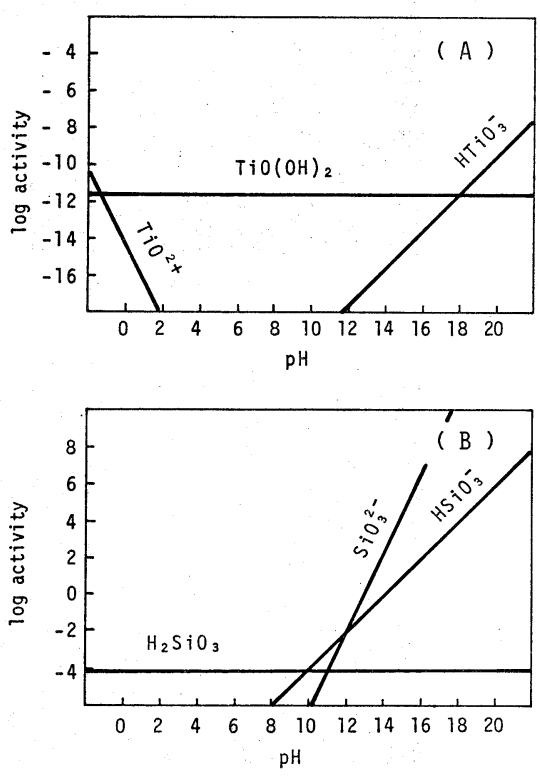

Fig. 6. Stability of (A) $\mathrm{TiO}_{2}$ (rutile), calculated by the authors and (B) $\mathrm{SiO}_{2}$ (vitreous), after $\mathrm{Paul}^{3)}$, in aqueous solutions at different $\mathrm{pH}$ at $25^{\circ} \mathrm{C}$. 
-56.690 及び $-37.595(\mathrm{kcal} / \mathrm{mol})$ であり, これらの 值を用い $\mathrm{Paul}^{3)}$ の方法によって $25^{\circ} \mathrm{C}$ の種々の $\mathrm{pH}$ の 水溶液中における $\mathrm{TiO}_{2}$ の水和物及びその解離イオンの 活動度を求めると, 図 6(A) の結果が得られる. 図 6(B) は， $\mathrm{Paul}^{3)}$ が報告した $25^{\circ} \mathrm{C}$ の種々の $\mathrm{pH}$ の水溶液中 における $\mathrm{SiO}_{2}$ の水和物及びその解離イオンの活動度で ある. 図 6 から， $\mathrm{TiO}_{2}$ のアルカリ性水溶液中に打ける 溶解度は, $\mathrm{SiO}_{2}$ のそれに比べ極めて小さいことが分る. $\mathrm{TiO}_{2}$ の溶解度がこのように小さいと, ガラスの侵食の 初期段階でごく少量の $\mathrm{TiO}_{2}$ が溶出しただけで，水溶液 中の $\mathrm{TiO}_{2}$ 濃度はその飽和濃度に近づくと考えられる. ガラス表面付近においては，特にその傾向が大きいであ ろう。したがって，A-10 Zr ガラスから溶出した微量の $\mathrm{TiO}_{2}$ がそれ以後のガラスの侵食を抑制するのは，その 微量の $\mathrm{TiO}_{2}$ だけでガラス表面付近の $\mathrm{TiO}_{2}$ 濃度が飽 和濃度に近づき，それ以後の $\mathrm{TiO}_{2}$ の溶出が著しく抑制 されるためと考えられる。

一方, Scholder ら ${ }^{10)}$ によれば, $20^{\circ} \mathrm{C}$ の $1.8 \mathrm{~N} \mathrm{NaOH}$ 水溶液中に扮ける $\mathrm{BaO}$ の溶解度は $0.549 \mathrm{~g} / 100 \mathrm{cc}$ sat. soln. $(5.49 \mathrm{mg} / \mathrm{ml})$ であり, $\mathrm{TiO}_{2}$ の溶解度ほど小さく ない。したがって，水溶液中に溶出した微量の $\mathrm{BaO}$ が それ以後のガラスの侵食を抑制する原因は， $\mathrm{TiO}_{2}$ の場 合のように溶解度だけでは説明できない，それにもかか わらず, 先にも記したように, ごく少量の $\mathrm{Ba}(\mathrm{OH})_{2}$ ・ $8 \mathrm{H}_{2} \mathrm{O}$ をあらかじめ $\mathrm{NaOH}$ 水溶液に添加（BaO 0.02 $\mathrm{mg} / \mathrm{ml}$ に相当）しておくと， A-10 Zr ガラスの繊維の 侵食量は低下する。この原因は, 水溶液中の $\mathrm{BaO}$ の平 均濃度がその飽和濃度よりかなり低い場合でも，ガラス 表面付近の $\mathrm{BaO}$ 濃度は吸着により飽和濃度に近づき， その結果ガラスからの $\mathrm{BaO}$ の溶出が抑制されるためで あると考えられる．上記のように，ガラスの侵食の初期 段階で $\mathrm{TiO}_{2}$ の溶出が抑制されると, 結果としてガラス の表面付近に相対的に $\mathrm{TiO}_{2}$ に富む層が形成される. $\mathrm{TiO}_{2}$ は一般にアルカリ性水溶液中で種々の陽イオンを 吸着しやすい"11)ので, ガラス表面の $\mathrm{TiO}_{2}$ む $\mathrm{Ba}^{2+}$ イオ ンを特に強く吸着し，ガラス表面付近の $\mathrm{BaO}$ 濃度を高 めるものと考えられる。したがって，A-10 Z r ガラスか ら溶出した微量の $\mathrm{BaO}$ も同様の機構によってそれ以後 の $\mathrm{BaO}$ の溶出を抑制するであろうと考えられる.

このように，ガラスの主成分である $\mathrm{TiO}_{2}$ と $\mathrm{BaO}$ の 溶出が上記のような機構で抑制されると, 結果としてガ ラス表面付近に相対的に $\mathrm{TiO}_{2}$ と $\mathrm{BaO}$ に富む層が形成 され，その層厚が次第に大きくなるであろう．その層厚 が大きくなると，その層により $\mathrm{Na}_{2} \mathrm{O}$ や $\mathrm{Al}_{2} \mathrm{O}_{3}$ のガラ ス内部から表面への拡散が阻害され，これらの成分の溶 出も抑制されることになると考えられる。

ガラスの侵食が以上のような機構により抑制されると すると, $\mathrm{Na}_{2} \mathrm{O}-\mathrm{BaO}-\mathrm{Al}_{2} \mathrm{O}_{3}-\mathrm{TiO}_{2}$ 系のガラス粉末の侵食
が，ガラス中の $\mathrm{TiO}_{2}$ 及び $\mathrm{BaO}$ 含有量が大きくなるに つれ進みにくくなった実験結果（図 3 ）もよく理解でき る.

表 1 の実験結果によれば，ガラス粉末の侵食は $\mathrm{Na}_{2} \mathrm{O}$ $\mathrm{BaO}-\mathrm{Al}_{2} \mathrm{O}_{3}-\mathrm{TiO}_{2}$ 系組成の $\mathrm{TiO}_{2}$ の一部を $\mathrm{ZrO}_{2}$ で置 換すると更に進みにくくなる。これは， $\mathrm{ZrO}_{2}$ のアルカ リ水溶液中における溶解度 ${ }^{3)}$ が， $\mathrm{TiO}_{2}$ のそれより更に 低いためであると考えられる．すなわち， $\mathrm{TiO}_{2}$ の一部 がより溶解度の低い $\mathrm{ZrO}_{2}$ で置換されていると, アルカ リ侵食のより早い段階でガラス表面に難溶性の $\mathrm{BaO}$, $\mathrm{TiO}_{2}$ 及び $\mathrm{ZrO}_{2}$ に富む層が形成され，それによりそれ 以後のガラスの侵食が抑制されると考えられる.

$\mathrm{ZrO}_{2}$ が $\mathrm{Na}_{2} \mathrm{O}-\mathrm{BaO}-\mathrm{Al}_{2} \mathrm{O}_{3}-\mathrm{TiO}_{2}-\mathrm{ZrO}_{2}$ 系ガラスの侵 食を抑制する効果沙, $\mathrm{NaOH}$ 水溶液中に $\mathrm{Z}, \mathrm{rO}_{2} \cdot 2.7 \mathrm{H}_{2} \mathrm{O}$ の粉末を少量添加しておいた場合にもわずかながら認め られる (表 3 ). その抑制機構は $\mathrm{TiO}_{2}$ のそれと同様で あろうと推定される。それにもかかわらず，その抑制効 果が $\mathrm{TiO}_{2}$ のそれほど大きくないのは, ガラス中の $\mathrm{ZrO}_{2}$ 含有量が $\mathrm{TiO}_{2}$ 含有量よりかなり低いためであると考え られる。

ガラス中の $\mathrm{ZrO}_{2}$ がガラスの侵食を抑制する効果は， $\mathrm{G} 20$ ガラスのような $\mathrm{Na}_{2} \mathrm{O}-\mathrm{SiO}_{2}-\mathrm{ZrO}_{2}$ 系ガラスの場合 にも認められる ${ }^{12)}$ ，それにもかかわらず， $\mathrm{Na}_{2} \mathrm{O}-\mathrm{BaO}$ $\mathrm{Al}_{2} \mathrm{O}_{3}-\mathrm{TiO}_{2}-\mathrm{ZrO}_{2}$ 系のガラス粉末が, $\mathrm{G} 20$ ガラス粉末 より $\mathrm{NaOH}$ 水溶液にはるかに侵食されにくい結果を示 したのは，主に前者のガラスがアルカリ水溶液中でガラ スの侵食を抑制する $\mathrm{BaO}$ 及び $\mathrm{TiO}_{2}$ を多量に含むため であると考えられる.

謝 辞 本研究の一部は文部省科学研究費補助金 (昭和 53 年度一般研究 (B) 347061) の援助を受けて行った.ここに謝意 を表します。

\section{文献}

1) A.J. Majumder and J.E. Ryder, Glass Technol., 9, 78-84 (1968).

2) 久米 真, セラミックス, 14, 227-30 (1979).

3) A. Paul, J. Mater. Science, 12, 2246-68 (1977).

4) T. Kokubo and M. Tashiro, Bull. Inst. Chem. Res., Kyoto Univ., 52, 633-40 (1974).

5) G. Bayer, O.W. Flörke and G. Tümker, Glastechn. Ber., 50, 137-43 (1977).

6）作花済夫, 境野照雄, 高橋克明編 “ガラスハンドブック” 朝倉書店 (1975) . p. 226.

7) V. Auger, Compt. Rend., 177, 1320 (1923); W.F. Linke, "Solubilities of Inorganic and Metal-organic Compounds", Vol. 2, 4th ed., Am. Chem. Soc., Washington D.C. (1965) p. 1554.

8) J.W. Spraner and D.W. Pearce, J. Phys. Chem., 44, 909 (1940). 上記 “Solubilities of Inorganic and Metalorganic Compounds", Vol. 2, p. 1165 所載.

9) M. Pourbaix, "Atlas of Electrochemical Equilibria in Aqueous Solutions", Pergamon Press, London (1966) 
p. 214.

10) R. Scholder and R. Pätsch, Z. Anorg. Chem., 222, 135-44 (1935). 上記 "Solubilities of Inorganic and Metal-organic Compounds", Vol. 1, p. 378-79 所載.
11) C. Heitner-Wirguin and A. Albu-Yaron, J. Inorg. Nucl. Chem., 28, 2379-84 (1966).

12）鷹木 洋, 小久保 正, 田代 仁，致協，89，243-51 (1981).

論 文・Paper

\title{
熱分解炭素粉末の電気抵抗の温度及びふん囲気依存性
}

\author{
加藤悦朗・村瀬嘉夫*・立松康政 \\ $(*$ 名古屋工業大学 無機材料工学科 $)$
}

炭素セラミック系複合抵抗体の温度及びふん囲気安定性の基礎研究として，熱分解炭素を用い， 炭素層平面に垂直及び平行方向の接触抵抗をそれぞれ反映するようにセットされた薄片積層 $[\mathrm{F}]$ 及び自由堆積状態粉末 $[\mathrm{P}]$ の, 室温 $300^{\circ} \mathrm{C}$ でのふん囲気変化による抵抗変化を測定した.

抵抗の対数々絶対温度の逆数の関係は $[\mathrm{P}]$ では湾曲するが $[\mathrm{F}]$ では傾斜小のほぼ直線である. $[\mathrm{P}],[\mathrm{F}]$ ともに導電の見掛けの活性化エネルギーは炭素の熱処理温度（HTT）が高いほど小さく なり， $2500^{\circ} \mathrm{C}$ 程度以上の $\mathrm{HTT}$ で熱分解黒鉛の体積抵抗のそれに扔拉よそ等しくなる.

[P] の抵抗に対する $200^{\circ} \sim 300^{\circ} \mathrm{C}$ での空気中酸素の効果は炭素の HTT によって異なり，面間 隔が乱層構造のそれに等しくなる温度より HTT が低いか高いかによって抵抗を増大又は減少させ る. [F] の抵抗は酸素によって HTT に関係なくすべて減少する. 炭酸ガス, 水蒸気, ベンゼン 蒸気，プロパン，都市ガス等は $[\mathrm{P}]$ と [ F $]$ に対しそれぞれ特徴ある抵抗変化挙動を示す。これら の変化は酸素の場合之異なり，炭素の HTT には関係がなく，いずれも $[\mathrm{P}]$ か $[\mathrm{F}]$ かで異なる. $200^{\circ} \sim 300^{\circ} \mathrm{C}$ での抵抗に及ぼす空気中酸素の特異な効果は, 層平面末端炭素やそれらを接合する 未組織炭素に対しては障壁を高正孔の移動度を低下させ, 層構造炭素に対しては吸着酸素への電 子の移行によって正孔濃度を増大させるとして説明することができる.

(1980 年 10 月 29 日受付)

\section{Temperature- and Atmosphere-dependence of Electric Resistance of Pyrolytic Carbon Powders}

\author{
Etsuro KATO, Yoshio MURASE* and Yasumasa TATEMATSU \\ $\left(\begin{array}{l}\text { Department of Inorganic Materials, Nagoya Institute of Technology } \\ \text { Gokiso-cho, Showa-ku, Nagoya-shi } 466 \\ * \text { Government Industrial Research Institute, Nagoya }\end{array}\right)$
}

Effects of atmosphere on the electric resistances of the flakes and powders of pyrolytic carbon at temperatures up to $300^{\circ} \mathrm{C}$ were studied to obtain basic imformations on the stability of carbon ceramic composite resistors. The changes in the resistances were measured for the flakes in piled state $[\mathrm{F}]$ or the freely heaped powders $[\mathrm{P}]$, which were set to represent mainly contact resistance respectively perpendicular or parallel to the basal plane of carbon structure.

The relations between logarithmic resistance and reciprocal absolute temperature were significantly curved in $[\mathrm{P}]$ and nearly straight with lower slope in $[\mathrm{F}]$. The apparent activation energies of electric conduction for both $[\mathrm{P}]$ and $[\mathrm{F}]$. were lowered with raising the previous heat-treatment temperature (HTT), and approximated to those in bulk of pyrolytic graphite blocks at HTT s above about $2500^{\circ} \mathrm{C}$.

The electric resistance of $[\mathrm{P}]$ was increased or decreased with air at $200^{\circ} \sim 300^{\circ} \mathrm{C}$ according 